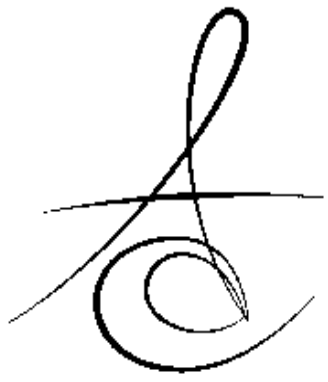

Makale Kodu/Article code: 2447

Makale Gönderilme tarihi: 27.10 .2015

Kabul Tarihi: 20.06.2016

\section{THE USE OF HYALURONIC ACID HYDROGELS FOR TISSUE REGENERATION IN ORAL SURGERY: A REVIEW}

\author{
HYALURONİK ASİT HİDROJELLERİNİN ORAL CERRAHİDE DOKU \\ REJENERASYONUNDA KULLANIMI: DERLEME
}

Arş. Gör. Dt. Özlem AKBELEN KAYA* Prof. Dr. Mehtap MUĞLALI*

\section{ABSTRACT}

Hyaluronic acid (HA) is a naturally occurring linear polysaccharide of the extracellular matrix of connective tissue, synovial fluid, and other tissues. It possesses various physiological and structural functions, which include cellular and extracellular interactions, interactions with growth factors and regulation of the osmotic pressure, and tissue lubrication. All these functions help in maintaining the structural and homeostatic integrity of the tissue. Extensive studies on the chemical and physicochemical properties of HA and its physiological role in humans have proved that it is an ideal biomaterial for cosmetic, medical, and pharmaceutical applications.

The aim of this review article is to discuss various physiochemical, biochemical, and pharmaco- therapeutic uses of $\mathrm{HA}$, especially in relation to the regeneration of oral tissues. The Pubmed/Medline database was searched and only highly relevant articles from electronic and manual search in English literature were selected for the present review article.

Key words: hyaluronic acid, tissue regeneration, dentistry

\section{Background}

Hyaluronic acid (HA) is also known as hyaluronan or hyaluronate. ${ }^{1}$ It is a linear polysaccharide found in extracellular matrices of connective tissue, synovial fluid and other tissues. ${ }^{2}$ HA is produced by fibroblasts in the presence of endotoxins. In the 19th century, carbohydrates were believed to be hydrates of carbon, with the general formula $\mathrm{C}_{n}\left(\mathrm{H}_{2} \mathrm{O}\right)_{n}$. Levene and LopezSuarez ${ }^{3}$, isolated a polysaccharide containing glucosamine, glucuronic acid and sulfate, which they named mucoitin sulfuric acid. It was probably HA but

\section{öz}

Hyaluronik asit (HA) konnektif dokunun, sinoviyal sıvının ve diğer dokuların ekstrasellüler matriksinde doğal olarak var olan lineer bir polisakkarittir. Hücresel ve hücre dışı etkileşimler, büyüme faktörleri ve ozmotik basıncın düzenlenmesi, dokuların lubrikasyonu dahil çeşitli fizyolojik ve yapısal fonksiyonlara sahiptir. Bütün bu fonksiyonlar dokunun yapısal ve homeostatik bütünlüğünü korumaya yardımcı olur. HA'nın kimyasal ve fizikokimyasal özellikleri ve bu özelliklerinin organizmadaki fizyolojik rolü üzerine yapılan kapsamlı çalışmalar; HA'nın kozmetik, medikal ve ilaç uygulamaları için ideal bir biyomateryal olduğunu kanıtlamıştır.

Bu derlemenin amacl; HA'nın diş hekimliğinde doku rejenerasyonu alanında fizikokimyasal, biyokimyasal ve farmako-terapötik olarak çeşitli kullanımlarını tartışmaktır. Derlemede makaleler Pubmed / Medline veritabanında aranmış ve ingilizce taramada sadece amaca uygun ilgili makaleler seçilmiştir.

Anahtar kelimeler: hyaluronik asit, doku rejenerasyonu, diş hekimliği

incorrectly assumed to contain sulfate. Proteoglycans are a unique class of glycoconjugate comprising a core protein to which one or more glycosaminoglycan chains, as well as $\mathrm{N}$ - and O-linked oligosaccharides are covalently bound. HA is a naturally occurring non- sulfated glycosaminoglycan with high molecular weight of 4000-20.000.000 daltons. HA structure consists of polyanionic disaccharide units of glucoronic acid and $\mathrm{N}$-acetyl glucosamine connected by alternating $\beta 1-3$ and $\beta 1-4$ bonds. ${ }^{4}$

$\mathrm{HA}$ is one of the most hygroscopic molecules known in nature. When HA is incorporated into

*Ondokuz Mayıs Üniversitesi Diş Hekimliği Fakültesi, Ağız Diş ve Çene Cerrahisi AD 
aqueous solution, hydrogen bonding occurs between adjacent carboxyl and $\mathrm{N}$-acetyl groups; this feature allows HA to maintain conformational stiffness, viscoelasticity and to retain water. $1 \mathrm{~g}$ of $\mathrm{HA}$ can bind up to $6 \mathrm{~L}$ of water. As a physical background material; it has functions in space filling, lubrication and shock absorption. $^{5}$

Through its complex interactions with matrix components and cells, it has multifaceted roles in biology utilizing both its physiochemical and biological properties. These biological roles range from a purely structural function in the extracellular matrix to development regulation through effects of cellular behavior through control of the tissue macro and micro-environments, as well as through direct receptor mediated effects on gene expression. Among extracellular matrix molecules, it has unique hygroscopic and viscoelastic properties. HA synthesis contributes to local foci of tissue hydration, which is important during cell proliferation and migration. These local foci of tissue hydration weaken cell attachment to the extra cellular matrix allowing temporary detachment to facilitate cell migration and division. In inflammation, HA has a moderating effect through free radical scavenging as well as the exclusion of tissue degrading enzymes such as metalloproteinase All these properties along with the release of cytokines when $\mathrm{HA}$ binds to its specific receptor $C D-44$ explains $H A$ has a key role in the healing process. ${ }^{6}$ The function of $\mathrm{HA}$ in vital tissues are summarized and presented in Table 1..$^{7-12}$

Many reports have attested to the effects of exogenous $\mathrm{HA}$ in producing beneficial wound healing outcome. Hellstrom and Laurent have shown that HA applied onto experimentally made soft tissue perforations increases the healing rate. Application of $\mathrm{HA}$ onto the perforated area also influences the structural quality of the healed tissue. ${ }^{13}$ Prolonged presence of $\mathrm{HA}$ has been reported to be associated with the scarless quality of fetal tissue repair. HA content in fetal wounds remains high for longer periods than in adult wounds, leading to the suggestion that HA may, at least in part, reduce collagen deposition and therefore lead to reduced scarring. ${ }^{14}$

HA preparations are first used in the medical field such as dermatology, orthopedics and ophthalmology. Then the preparations were used in the treatment of joint diseases follow arthrocentesis and found its place as the first application in oral and maxillofacial surgery. Studies indicate that HA influences the healing of hard and soft tissues in a positive direction. The use of $\mathrm{HA}$ in oral and maxillofacial surgery is recent and researches are still ongoing.

Table 1. The function of $\mathrm{HA}$

\begin{tabular}{|c|c|}
\hline $\begin{array}{c}\begin{array}{c}\text { Modulation } \\
\text { of } \\
\text { inflammation }\end{array} \mid \\
\end{array}$ & $\begin{array}{l}\text { HA exhibits a modulatory effect during the initial } \\
\text { stages of inflammation and enhances inflammatory } \\
\text { cell and extracellular matrix cell infiltration into the } \\
\text { wound site. It causes elevation in pro-inflammatory } \\
\text { cytokine production by inflammatory cells and } \\
\text { extracellular matrix cells, also helps in the } \\
\text { organization and stabilization of granulation tissue } \\
\text { matrix. It scavenges reactive oxygen species, such } \\
\text { as superoxide radical and hydroxyl radical thus } \\
\text { preventing periodontal destruction. }\end{array}$ \\
\hline $\begin{array}{c}\text { Stimulation } \\
\text { of cell } \\
\text { migration, } \\
\text { proliferation } \\
\text { and differen } \\
\text { tiation }\end{array}$ & $\begin{array}{l}\text { The remarkable hydrophilicity of the HA makes the } \\
\text { coagulum more receptive and thus more likely to } \\
\text { undergo colonization by the cells committed to the } \\
\text { reconstruction of the damaged tissue by migration, } \\
\text { proliferation and differentiation of mesenchymal and } \\
\text { basal keratinocytes. }\end{array}$ \\
\hline \begin{tabular}{|c|} 
Effect on \\
angiogenesis
\end{tabular} & $\begin{array}{l}\text { It has been proposed that an accelerated wound } \\
\text { healing in the bone matrix will occur due to } \\
\text { stimulation of angiogenesis by HA. }\end{array}$ \\
\hline $\begin{array}{c}\text { Osteocondu } \\
\text { ctive } \\
\text { potential }\end{array}$ & $\begin{array}{l}\text { HA accelerates the bone regeneration by means of } \\
\text { chemotaxis, proliferation and successive } \\
\text { differentiation of mesenchymal cells. HA shares } \\
\text { bone induction characteristics with osteogenic } \\
\text { substances such as bone morphogenetic protein-2 } \\
\text { and osteopontin. These are completely } \\
\text { biodegradable and support the growth of fibroblasts, } \\
\text { chrondrocytes and mesenchymal stem cells. }\end{array}$ \\
\hline $\begin{array}{c}\text { Carrier } \\
\text { function }\end{array}$ & $\begin{array}{l}\text { HA may act as a biomaterial scaffold for other } \\
\text { materials, such as bone morphogenic protein- } 2 \text { and } \\
\text { platelet derived growth factor used in guided bone } \\
\text { regeneration techniques and tissue engineering } \\
\text { research. }\end{array}$ \\
\hline $\begin{array}{c}\text { Bacteriosta } \\
\text { tic effect }\end{array}$ & $\begin{array}{l}\text { Recent studies on regenerative surgical procedure } \\
\text { indicate that reduction of bacterial burden at the } \\
\text { wound site may improve the clinical outcome of } \\
\text { regenerative therapy. The high concentration of } \\
\text { medium and lower molecular weight of HA has the } \\
\text { greatest bacteriostatic effect particularly on } \\
\text { Aggregatibacter actinomycetemcomitans, Prevotella } \\
\text { oris and Staphylococcus aureus strains commonly } \\
\text { found in oral gingival lesions and periodontal } \\
\text { wounds. Clinical application of HA membranes, gels } \\
\text { and sponges during surgical therapy may reduce the } \\
\text { bacterial contamination of surgical wound site, } \\
\text { thereby, lessening the risk of post-surgical infection } \\
\text { and promoting more predictable regeneration. }\end{array}$ \\
\hline
\end{tabular}

The aim of this review article is to introduce the function of $\mathrm{HA}$ in wound healing and discuss various physiochemical, biochemical, and pharmacotherapeutic uses of $\mathrm{HA}$, especially in relation to the regeneration of oral tissues in oral surgery.

\section{MATERIALS AND METHODS}

We conducted a Pubmed/Medline based search of literature including written articles in English published between 2005 and 2016 using query

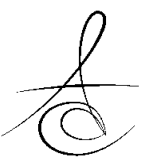


'hyaluronic acid, tissue regeneration, dentistry, oral surgery". For the general view on the structure and mechanism of HA we searched data from general medicine and biochemistry. Clinical applications of HA in oral surgery were searched from the literature of dentistry and oral and maxillofacial surgery. The trials about the effect of $\mathrm{HA}$ on tissue regeneration and wound healing were classified into in-vivo and in-vitro studies. Only randomized controlled clinical trials included in this review (Table 2).

Table 2. İncluded trials

\begin{tabular}{|l|l|l|l|}
\hline Author & Year & $\begin{array}{l}\text { Operation/ clinical } \\
\text { situation type }\end{array}$ & Application type \\
\hline Vanden & 2009 & Infrabony defects & HA alone \\
\hline $\begin{array}{l}\text { Fawzy El- } \\
\text { Sayed et al }\end{array}$ & 2012 & Periodontal surgery & HA alone \\
\hline $\begin{array}{l}\text { Bogaerde et al } \\
\text { De Santana and } \\
\text { De antana }\end{array}$ & 2009 & Infrabony defects & HA alone \\
\hline $\begin{array}{l}\text { Baldini et al } \\
\text { Ballini et al }\end{array}$ & 2010 & $\begin{array}{l}\text { Extraction sockets } \\
\text { preservation }\end{array}$ & $\begin{array}{l}\text { HA + autologus } \\
\text { bone }\end{array}$ \\
\hline $\begin{array}{l}\text { Andrea et al } \\
\text { Nolan et al }\end{array}$ & 2009 & Infrabony defects & $\begin{array}{l}\text { HA + autologus } \\
\text { bone }\end{array}$ \\
\hline Nolan et al & 2009 & Aphthous ulser & $\begin{array}{l}\text { HA + autologus } \\
\text { bone }\end{array}$ \\
\hline Koray et al & 2014 & $\begin{array}{l}\text { Impacted third molar } \\
\text { surgery }\end{array}$ & HA alone \\
\hline Gocmen et al & 2015 & $\begin{array}{l}\text { Impacted third molar } \\
\text { surgery }\end{array}$ & HA alone \\
\hline
\end{tabular}

\section{DISCUSSION}

Though HA is a newly developed biomaterial in dentistry, some recent clinical studies were done on HA for topical application and as a biomaterial assisting regeneration.

Vanden ${ }^{15}$ in 2009, investigated the clinical efficacy of esterified HA (in the form of fibers) for treating deep periodontal defects. 18 infrabony defects and 1 mandibular molar furcation had been selected for placing the HA fibers. After 1 year of treatment the mean probing pocket depth was reduced by $5.8 \mathrm{~mm}$ and the attachment gain was 2.8 $\mathrm{mm}$. Fawzy El-Sayed et $\mathrm{al}^{16}$, in a randomized controlled trial, evaluated the effect of local application of $0.8 \% \mathrm{HA}$ gel in conjunction with periodontal surgery. After initial non-surgical periodontal therapy and reevaluation, defects were randomly assigned to be treated with modified widman flap surgery in conjunction with either $0.8 \% \mathrm{HA}$ gel (test) or placebo gel (control) application. Statistically, significant differences were noted for clinical attachment level and gingival recession, in favor of the test sites. But non- significant results were found regarding PPD, BOP and PI values.

De Santana and De Santana ${ }^{17}$ reported a study about application of $\mathrm{HA}$ and fibroblast growth factor type 2 (rhFGF-2) together to the infrabony defects. As a result of the study they indicated that $\mathrm{HA}$ was a suitable carrier for rhFGF-2 and their application together provided sufficient bone fill and attachment gain.

Bogaerde et $\mathrm{al}^{18}$ in a clinical trial, applied HA gel to deep periodontal bony defects. They recorded probing pocket depth, gingival recession, clinical attachment level in each defect and compared these measurements with the measurements performed after one year. They found out decrease in probing pocket depth $5,8 \mathrm{~mm}$, increase in gingival recession 2 $\mathrm{mm}$ and observed $3,8 \mathrm{~mm}$ clinical attachment gain. Researchers reported that gingival recession was observed in only one wall defects, so HA may be more successful with the use of graft materials in these defects.

Ballini et $\mathrm{al}^{19}$, reported a study about the osteoinductive effect of HA by using an esterified HA preparation as a coadjuvant in the grafting processes to produce bone-like tissue in the presence of employing autologous bone to treat infra-bone defects without covering membrane. They found that autologous bone combined with an esterified HA preparation seems to have good capabilities in accelerating new bone formation in the infra- bone defects.

A study was done to demonstrate the osteoinductive effect of esterified HA preparation in the treatment of infrabony defects. It was used as a co-adjuvant with autologus bone for grafting procedure. At 9 months from the procedure, the dental parameters were virtually stable with a mean clinical attachment level gain of $2.6 \mathrm{~mm}$. Radiographic evaluations after 24 months had shown defect fill. The HA product called Hyaloss $\AA$ matrix (Anıca therapeutıcs Inc./Bedfordshire/England) were used in this study. The researchers indicated that Hyaloss $\AA$ matrix at room temperature formed a biodegradable, biocompatible gel that could be adapted by the operator to the desired consistency. According to their well, Hyaloss $\AA$ matrix has a dual function: on one hand, its physiochemical properties facilitate the application of bone graft in the defect site, and on the other hand, it creates an environment with a rich content of HA. ${ }^{20}$

A similar preliminary study results show an acceleration of the bone deposit process and of its

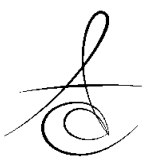


remodeling due to the presence of $\mathrm{HA}$, which, from a clinical point of view, improves the handling and application of the bone matrix inside the defects and, from a hystologic point of view makes it possible to obtain bone regeneration in less time when it is used with autologous bone in extraction sockets. ${ }^{21}$

Clinical studies about application of HA indicate same positive results. If it is used for periodontal soft tissue regeneration, single use of HA seems like sufficient. However in bone defects, studies demonstrate that its use with bone graft materials or osteoinductive growth factors may provide more bone gain. Generally for tissue regeneration, HA fastens this process, and it has a sufficient carrier function to hold graft particules together and be able to apply mechanically insufficient materials such as growth factors and stem cells.

There are few studies about HA application to the oral mucosal lesions due to search the barrier function of HA. Further more there are few studies about application of $\mathrm{HA}$ to the extraction socket of impacted third molars to evaluate the antiinflammatory and antioxidant effect of HA.

In a randomized controlled clinical tiral which included 120 patients with aphthous ulcers, Nolan et $\mathrm{al}^{22}$ had applied to $2 \% \mathrm{HA}$ gel the patients in the experimental group and placebo to the control group. As a result of the study, researchers found that in the group applied $\mathrm{HA}$, compared with the placebo group aphthous ulcers had improved more quickly and the number of newly formed lesions were less in the group treated with $\mathrm{HA}$ than the placebo group. Authors implied that HA showed the barrier function due to the viscoelastic structure and because of the anti-inflammatory properties, HA may be used as a successful therapeutic agent in the treatment of recurrent aphthous ulcers. Either a similar randomized double-blind study was carried out by Nolan et $\mathrm{al}^{23}$ to evaluate the efficacy of a topical $0.2 \% \mathrm{HA}$ gel preparation in the management of oral lichen planus. They demonstrated that the application of topical HA produced a significant reduction in soreness scores when compared with placebo for up to $4 \mathrm{~h}$ postapplication and the patients treated with $0.2 \% \mathrm{HA}$ showed a significant reduction in the size of the erosive/ulcerated area after 28 days of treatment when compared with baseline. The researchers indicated that HA might be a successful agent to decrease symptoms of oral lichen planus and provide healing more quickly in erosive lesions. According to the results of the trials of Nolan et $a^{22,23}, \mathrm{HA}$ may be useful in erosive mucosal and gingival lesions due to its barrier function. Also its bacteriostatic affect might be pro- moted this positive results in the trials of Nolan et al.

Koray et $\mathrm{al}^{24}$, have compared the use of $\mathrm{HA}$ and benzydamin hydrochloride sprays after impacted third molar surgery. Researchers have found no statistically significant difference in pain scores between two groups. However they have indicated that trismus and edema was significantly less in the HA group than benzydamin hydrochloride group. In a similar randomized controlled clinical trial that included 40 patients, Gocmen et $\mathrm{al}^{25}$ have applied $0.2 \mathrm{~mm}$ $0.8 \% \mathrm{HA}$ gel to the experimental group, not applied any preparation to the control group after impacted third molar surgery. In this study, glutathione and lipid peroxidation levels for oxidative stress in oral tissues; the amount of leukocytes, collagen and angiogenesis for inflammation; clinically pain and maximum mouth opening values were compared with the control group immediately and one week after the operation. Researchers have observed less leukocyte infiltration and more angiogenesis in the group treated with $\mathrm{HA}$, in other parameters they have found no statistically significant difference between the groups. As a result of the study, the authors reported that the anti-inflammatory effect of HA was a positive contribution to the process of healing after impacted third molar extraction, but the antioxidant effect was not statistically significant compared to the control group.

\section{CONCLUSION}

Thus, it is clinically evident that HA has a multifunctional role in the wound healing process. As a consequence of the many functions attributed to HA during wound healing, advances have been made in the development and application of HA-based biomaterials in the treatment of periodontal tissues, mucosal lesions for re-epithelialization and the regeneration of bone. Hence, further clinical trials with better standards such as application time, quantity of application, different forms and concentration need to be carried out for better understanding of tissue regeneration effect of HA in oral surgery practice.

\section{KAYNAKLAR}

1. Liguori V, Guillemin C, Pesce GF, Mirimanoff RO, Bernier J. Double- blind, randomized clinical study comparing hyaluronic acid cream to placebo in 
patients treated with radiotherapy. Radiother Oncol 1997;42:155- 61.

2. Orbak R, Ozturk M. Esthtetic applications at perioral region that fulfill intraoral treatments . J Dent Fac Atatürk Uni 2014;24:427-33.

3. Levene PA, Lopez-Suarez J. Mucins and mucoids. J Biol Chem 1918;36:105- 26.

4. Laurent TC. Hyaluronan before 2000. 1 ed. Abington, Cambridge; Woodhead Publishing: 2002. p. 3-8.

5. Laurent TC, Fraser JR. Degradation of Bioactive Substances: Physiology and Pathophysiology. 1 ed. Boca Raton, Florida; CRC Press: 1991. p. 249- 65.

6. Sutherland IW. Novel and established applications of microbial polysaccharides. Trends Biotechnol 1998; 16:41-6.

7. Weigel PH, Frost SJ, McGary CT, Le Boeuf RD. The role of hyaluronic acid in inflammation and wound healing. Int J Tissue React 1988;10:355-65.

8. Toole BP. Hyaluronan in morphogenesis. Semin Cell Dev Biol 2001;12:79-87.

9. Deed R, Rooney P, Kumar P, Norton JD, Smith J, Freemont $A J$, Kumar $S$. Early- response gene signalling is induced by angiogenic oligosaccharides of hyaluronan in endothelial cells. Inhibition by non-angiogenic, high-molecular-weight hyaluronan. Int J Cancer 1997;71:251- 6.

10. Bartold PM, Xiao Y, Lyngstaadas SP, Paine ML, Snead ML. Principles and applications of cell delivery systems for periodontal regeneration. Periodontol 2000 2006;41:123-35.

11. Hunt DR, Jovanovic SA, Wikesjö UM, Wozney JM, Bernard GW. Hyaluronan supports recombinant human bone morphogenetic protein- 2 induced bone reconstruction of advanced alveolar ridge defects in dogs: A pilot study. J Periodontol 2001;72:651-8.

12. Pirnazar P, Wolinsky L, Nachnani S, Haake S, Pilloni A, Bernard GW. Bacteriostatic effects of hyaluronic acid. J Periodontol 1999;70:370-4.

13. Longaker MT, Adzick NS. The biology of fetal wound healing: A review. Plast Reconstr Surg $1991 ; 87: 788-98$.

14. Engström- Laurent A. Changes in hyaluronan concentration in tissues and body fluids in disease states. Ciba Foundation Symposium 2007; 143: 233-47.

15. Vanden BL. Treatment of infrabony periodontal defects with esterified hyaluronic acid: Clinical report of 19 consecutive lesions. Int J Periodontics
Restorative Dent 2009;29:315-23.

16. Fawzy El-Sayed KM, Dahaba MA, Aboul-Ela S, Darhous MS. Local application of hyaluronan gel in conjunction with periodontal surgery: A randomized controlled trial. Clin Oral Investig 2012;16:1229-36.

17. De Santana RB, de Santana CM. Human intrabony defect regeneration with rhFGF-2 and hyaluronic acid - a randomized controlled clinical trial. J Clin Periodontol 2015;42:658-65.

18. Bogaerde LV. Treatment of Infrabony Periodantal defects with estrified hyaluronic acid: clinical report of 19 consecutive lesions. Int J Periodontics Restorative Dent 2009;29:315-23.

19. Ballini A, Cantore S, Capodiferro S, Grassi FR. Esterified Hyaluronic Acid and Autologous Bone in the Surgical Correction of the Infra-Bone Defects. Int J Med Sci 2009;6:65-71.

20. Andrea B, Stefania C, Roberto F. Esterified hyaluronic acid and autologous bone in the surgical correction of the infra-bone defects. Int J Med Sci 2009;62:334-40.

21. Baldini A, Zaffe D, Nicolini G. Bone-defects healing by high-molecular hyaluronic acid: preliminary results. Ann Stomatol 2010;1:2-7.

22. Nolan A, Baillie C, Badminton J, Rudralingham M, Seymour RA. The efficacy of topical hyaluronic acid in the management of recurrent aphthous ulceration. J Oral Pathol Med 2006;35:461-5.

23. Nolan A, Badminton J, Maguire J, Seymou RA. The efficacy of topical hyaluronic acid in the management of oral lichen planus. J Oral Pathol Med 2009;38:299-30.

24. Koray M, Ofluoglu D, Onal EA, Ozgul M, Ersev $H$, Yaltirik $M$, Tanyeri $H$. Efficacy of hyaluronic acid spray on swelling, pain, and trismus after surgical extraction of impacted mandibular third molars. Int J Oral Maxillofac Surg 2014;43:1399-403.

25. Gocmen G, Gonul O, Oktay NS, Yarat A, Goker K. The antioxidant and anti-inflammatory efficiency of hyaluronic acid after third molar extraction. J Craniomaxillofac Surg. 2015;43:1033-7.
Yazışma Adresi
Arş. Gör. Dt. Özlem AKBELEN KAYA
Ondokuz Mayıs Üniv Diş Hek Fak
Ağız Diş Ve Çene Cerrahisi Anabilim Dalı
Kurupelit ATAKUM/ SAMSUN
e-mail: ozlem_akbelen88@hotmail.com 